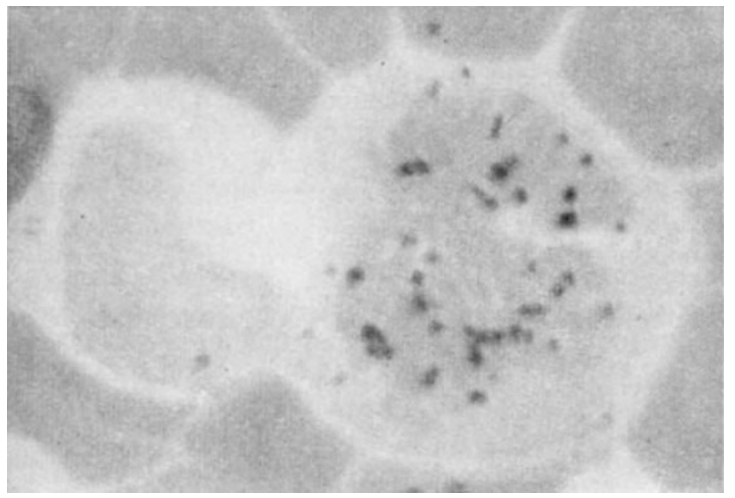

Fig. 2. Formate-11 $\mathrm{C}$ uptake by human bone marrow cells in vitro in 24 -hr. culture with $0 \cdot 75 \mu \mathrm{c} . / \mathrm{ml}$. formate- ${ }^{\mathrm{A}} \mathrm{C}$ medium. Smear $\times 2,000$. Note the localization of the isotope in the chromosomes

uptake by the cells. The difference in the specific activities $\left(1.04 \mathrm{mc} . / \mathrm{mM}\right.$ for formate ${ }^{14} \mathrm{C}$, and 1.56 $\mathrm{mc} . \mathrm{m} M$ for adenine ${ }^{-14} \mathrm{C}$ ) was compensated for in the exposure times of the autoradiographs, namely, ten days for adenine- ${ }^{14} \mathrm{C}$ slides and seventeen days for formate. ${ }^{14} \mathrm{C}$ slides. The grain counts on the acidhydrolysed slides indicated a similar amount of carbon-14 uptake in both cases, the average maximum uptake being of the order of $1.2 \times 10^{7}$ atoms of deoxyribonucleic acid. ${ }^{14} \mathrm{C}$.

However, the comparison of the non-hydrolysed and acid-hydrolysed preparations from the formate${ }^{14} \mathrm{C}$ cultures indicated scarcely any change in the average maximum grain counts after hydrolysis (see Fig. 1). The failure of acid hydrolysis to remove appreciable amounts of carbon-14 from the cells, together with the predominantly nuclear (and chromosomal) localization of the isotope on the nonhydrolysed preparations (Fig. 2), indicated that, as opposed to adenine ${ }^{14} \mathrm{C}$, most of the formate $-{ }^{14} \mathrm{C}$ taken up by human bone marrow cells in vitro is incorporated into deoxyribonucleic acid, and only a very small fraction is incorporated into other compounds (for example, ribonucleic acid).

These findings are at variance with those obtained in rat liver with formate ${ }^{14} \mathrm{C}^{4,5}$; but the cause of the difference may lie in the different rates of synthesis of deoxyribonucleic acid in bone marrow and resting liver. There is evidence that in chick bone marrow slices more than 70 per cent of the formate- ${ }^{14} \mathrm{C}$ in deoxyribonucleic acid is found in the methyl group of thymine $e^{6}$, and preliminary experiments in our laboratory also indicate that probably most of the formate- ${ }^{14} \mathrm{C}$ administered to human bone marrow cells in vitro is incorporated into thymine in deoxyribonucleic acid.

This work is part of an investigation carried out under a full grant from the British Empire Cancer Campaign.

L. G. LAJTHA

Department of Radiotherapy,

Oxford.
Aug. 5.

1 Lajtha, L. G., Nature, 173, 587 (1954).

- Lajtha

s Lajtha, Y. G., J. Phot. Sci. (in the press).

- Smellie, R. M. S., McIndoe, W. M., and Davidson, J. N., Biochim. Biophys. Acta, 11, 559 (1953).

- Payne, A. H., Kelly, L. S., Beach, G., and Jones, H. B., Cancer Research, 12, 426 (1952).

- Totter J. R Abstr. 1st Meeting Rad, Res. Soc., Iowa City, Radiation Research, 1, 232 (1954).

\section{Cocarboxylasic Activity of Thiamine Phosphoric Esters}

After the chemical synthesis of thiamine phosphoric esters was achieved ${ }^{1-4}$, reports were published on their cocarboxylasic activity ${ }^{3-7}$. Investigations have shown that monophosphothiamine has no cocarboxylasic activity, but different values have been found for the activity of triphosphothiamine. The diserepancies may be accounted for by the facts that : (a) chemical synthesis provides mixtures of three esters (mono-, di- and tri-phosphoric) which are very difficult to separate; $(b)$ diphosphothiamine is very active ; and therefore quantities as small as $0 \cdot 1 \gamma / \mathrm{ml}$. occurring as impurities with the other esters invalidate the results; $(c)$ washed yeast, which has usually been employed as apoenzyme, makes it difficult to reproduce results.

We have separated the esters by paper chromatography $^{7}$, employing Whatman No. 1 paper and $n$-propanol - water - $1 M$ acetate buffer, $p \mathrm{H} \quad 5$ $(70: 20: 10)$, as the solvent.

The position of each ester was established by developing duplicate spots in parallel and spraying one of the series. Fragments of strips not sprayed were placed in Warburg flasks and compared with known amounts of chromatographically pure diphosphothiamine under identical experimental conditions.

As apoenzyme we have used purified apocarboxylase according to Green et al. ${ }^{8}$. Each flask contained : an amount of apoenzyme which in the presence of excess $(80 \gamma)$ of diphosphothiamine produces carbon dioxide at $4.0 \times 10^{3} \mu \mathrm{l} . / \mathrm{hr}$. ; $0.27 \mathrm{mgm}$. of magnesium ions and $0.19 \mathrm{mgm}$. of manganese ions; in the side bulb, $0.4 \mathrm{ml}$. of $1.09 M$ sodium pyruvate; $0 \cdot 04 M$ citrate buffer, $p \mathrm{H} 6 \cdot 0$, making up the volume to $3.0 \mathrm{ml}$; ; temperature, $30^{\circ} \mathrm{C}$. ; atmosphere, air ; shaking, 160-170 oscillations/min. The rate of evolution of carbon dioxide was determined by a graphical method". The manometers were read every 2 min. after allowing $15 \mathrm{~min}$. for the establishment of equilibrium. The quantities of each ester were established by colorimetric determination of phosphorus $^{20}$.

The following results were obtained: (1) monophosphothiamine at concentrations of $0 \cdot 025-0 \cdot 13$ umol./ml. did not manifest any cocarboxylasic activity; (2) diphosphothiamine at a concentration of $0.04 \mathrm{umol}$./ml. liberated carbon dioxide at the rate of $2 \cdot 3 \times 10^{3} \mu \mathrm{l}$. $/ \mathrm{hr}$.; (3) triphosphothiamine at concentrations of $0.005-0.020 \mu \mathrm{mol} . / \mathrm{ml}$. did not manifest any cocarboxylasic activity.

\section{Gertrudis DE IA FUENTE \\ R. Df́az-Cadavieco}

Departamento de Bioquímica,

Instituto Español de Fisiología y Bioquímica,

Facultad de Farmacia, Ciudad Universitaria. Madrid.

Aug. 6.

${ }^{1}$ Weijlard, J., and Tauber, H., J. Amer. Chem. Soc., 60, 2263 (1938). ${ }^{2}$ Weil-Malherbe, H., Biochem. J., 34, 980 (1940).

3 Karrer, P., and Viscontini, M., Helv. Chim. Acta, 29, 711 (1946).

- Karrer, P. and Viscontini, M., Helv. Chim. Acta, 32, 1478 (1949).

5 Velluz, Amiard, G., and Bartos, J., Bull. Soc. Chim. France, 871 (1948).

- Velluz, L., Amiard, G., and Bartos, J., J. Biol. Chem., 180, 1137

(1949).
" Siliprandi, D., and Siliprandi, N., Biochim. Biophys. Acta, 14, 52 (1954).

Green, D. E. Herbert, D., and Subrahmanyan, V., J. Biol. Chem., 138, 327 (i941).

- Gertrudis de la Fuente (unpublished work).

${ }_{10}$ Fiske, C. H., and SubbaRow, Y., J. Biol. Chem., 66, 375 (1925). 